\title{
Socialist Content in National Form: A Guiding Principle of the "Communist Project" in Romanian Architecture
}

\author{
Horia Mihai-Coman ${ }^{1 *}$ \\ 1 Doctoral School, Faculty of Architecture and Urban Planning, Technical University of Cluj-Napoca, 400000 Cluj-Napoca, \\ Observatorului Street 34-36, Romania \\ * Corresponding author, e-mail: mihaicomanhoria@gmail.com
}

Received: 31 July 2019, Accepted: 24 February 2020, Published online: 30 March 2020

\begin{abstract}
The article follows the theme of "socialist content in national form" in Romanian architecture during a period stretching from approximately 1944 to 1989 - a time interval that is usually associated with the specific political agenda that dominated society in a decisive and profound way throughout the era, which is usually indicated as "communism". This time interval can also be indicated by using other keywords and concepts, such as "socialism", "state socialism", "totalitarianism" or others, sometimes in association with the keyword "communism". For reasons that will be presented in the introduction, the title of the article will prefer the use of the term "the communist project" for indicating the chronological focus of the article; the word "project" also holds a conceptual meaning - therefore being considered appropriate in the context of a mostly conceptual discussion that the article focusses on - as it tries to examine one of the most powerful and influential key concepts of the era: "socialist content in national form".
\end{abstract}

Keywords

aesthetics, style, socialist realism, socialist modernism, national specificity, traditionalism

\section{Introduction}

The "communist period" is one of the most frequent labels attached to a specific period in Romanian history. It is considered to have started at the end of the Second World War, with the rise to power of a group of individuals and activists usually described as communists. They were an initiative and action group with a communist agenda, organised in various entities bearing several names, the most customary one being "the communist party".

Chronologically speaking, the start of the communist period in Romania is not a precise date in history, as "the communists" (as to use the most eloquent denomination of this group) took power gradually, over a matter of years, from around 1944 to 1947 . The exact beginning of the period is debatable (1944, 1947 and 1948 being the most frequent candidate years for a formal beginning of the period). The end of it is arguably more precise, with the Romanian Revolution of December 1989, following which the communist regime dramatically collapsed both factually and formally, with the execution of the communist leader of the country, dictator Ceauşescu. Otherwise, alongside "communist", "socialist" is another term that is frequently used for indicating the target period.
The two notions (communist and socialist) partially overlap and have been used in different contexts throughout the period. For instance, the formal name of the republic was the People's Republic of Romania (Republica Populară Română) from 1947 to 1965, and then the Socialist Republic of Romania (Republica Socialistă România) from 1965 to 1989 , whereas the formal name of the political organisation in charge of the policies of the republic was not always the Communist Party, but also, from 1954 and 1965, the Workers' Party (Partidul Muncitoresc Român).

Therefore, because of the arguably imprecise and problematic nature of the labelling - and of the time intervals that can be associated with the various labels - the article will use "communist project" to indicate the target context of the research: the timeframe between approximate dates of 1947 and 1989. This period was when communism (considered as a doctrine, first and foremost) was probably the most representative and powerful modelling force in Romanian society - thus ultimately defining an era (not necessarily in a formal and precise way but, rather, in a conceptual one). Otherwise, in regards to this article, the use of the keyword "communist" will be favoured and 
prioritised instead of other arguably adequate formulas such as "socialist", "state socialist" or "totalitarian", while assuming the limitations and the partial imprecision of its uses, in the different contexts that will occur.

Two arguments can be presented to support the choice for the use of the expression "the communist project", as follows. One would be the use by Prof. Dr. arch. Ana Maria Zahariade, a leading Romanian researcher in the field, a witness of the communist period both as student architect and then as practicing architect. Zahariade has used the same term in the title of one of her books about the architecture of the target period (otherwise one of the most critically acclaimed books of her career): Architecture in the Communist Project. Romania 1944-1989 (Zahariade, 2011). Another reason would be that the research topic of the article ("socialist content in national form") is arguably a concept typical of the period, and the expression "the communist project" has an embedded conceptual meaning when it is formulated in this way (mainly because of the use of the word "project", in relation with "communism"). Thus, the two key phrases of the article ("socialist content in national form" and "the communist project") can be fruitfully associated, by using the conceptual common ground.

\section{The origins: The Stalinist period}

Succeeding in obtaining a "socialist content in national form" was one of the most frequent and sought-after objectives of the discourse on architecture at the beginning of the communist period (or "project") in Romania. Following the end of the Second World War, the first years of communism in Romania witnessed a widespread colonisation of Romania by the Soviet Union, which considered various aspects of life and fields of activity such as economic, ideological and cultural. "Colonisation", in this sense, is a term used and supported by an important number of acclaimed researchers in the field. It was not surprising that the aesthetic discourse of the USSR was also adopted or colonised in Romania. In terms of ideology, aesthetics and culture, the Soviet model of that time was "socialist realism" - sometimes referred to (mostly post-factum) even as frankly as "Stalinism". Socialist realism is mostly remembered and perceived as the Stalin-era stylistic response or solution to the aesthetic goal of "socialist content in national form" - a very popular idiom of the Soviet political discourse since 1918 when the Declaration of Rights of the Working and Exploited People, issued by the Third All-Russian Congress of the Soviets, advocated for the reformation of cultures as "national in form, socialist in content" (Shelestyuk, 2019:p.3). Alternatively, using Zahariade's words, socialist realism is the "principle of artistic creation of socialist content in national form" (Zahariade, 2011:p.32).

Therefore, being the official aesthetic construct of most of the Stalinist era, socialist realism ended up being adopted by Romania, gradually and with Soviet "guidance" (a term of the era), in the years following the end of the war (from around 1947 onwards). By 1952, the formula "socialist in content, national in form" had even entered Romania's constitution (The Constitution of the People's Republic of Romania, Art. 17). As a method of artistic creation, an aesthetic abstraction with ideological basis, or even a specific style, among other possible labels or interpretations that it can accommodate, socialist realism mixes elements of architectural style with elements of political ideology. In visual terms, it is recognised mainly by the use of stylistic quotations of arguably prestigious historical styles, such as Italian Renaissance or Greek Classicism: columns, porticos, pilasters, ornate capitals, decorative pediments and gables, shapes and volumes resembling temples (see Fig. 1). The decorative elements can be simplified and essentialised, monumentalised and scaled. They can also retrieve decorative motifs from more local or regional styles or sub-styles, alongside the usual classical ones. Perhaps surprisingly, the historical decorative motifs are combined with communist symbols, such as the sickle and the hammer, or the 5-point star.

In terms of building layouts, socialist realism promoted the "cvartal", which is a Soviet term used for unity of vicinity. The term indicates an arguably small group

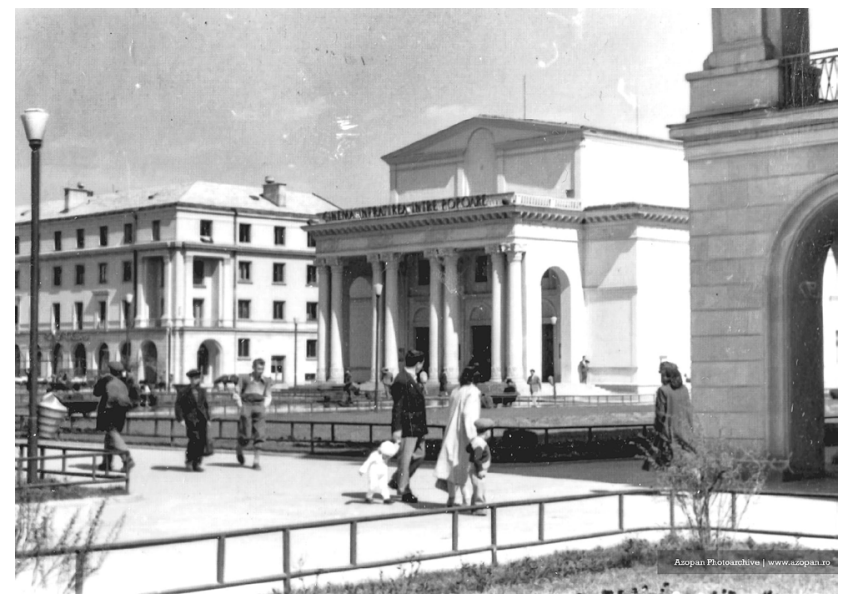

Fig. 1 "Socialist content in national form", 1950s, Stalin era: urban ensemble in Bucureștii Noi quarter of Bucharest, composed of housing blocks and a cinema, using the formula of the "cvartal". (Döri, 1959) 
of buildings (usually blocks of flats) that encircle a courtyard. Making use of cvartals and applied decoration in the design of ensembles, Soviet urbanism of the Stalin era can be recognised by its rather conservative image, boasting quite monumental buildings arranged in usually semiclosed courtyards. This is in contrast to the "exploded space" and interplay of "lines and points" of the free urbanism promoted by the functionalist agenda, which is contemporary with socialist realism and dominated the discourse and practice of architecture and urbanism in Western Europe at that time. For ideological reasons at least, socialist realism had a goal in adopting an aesthetic programme and identity that was different from the Western one, while criticising Western culture in its functionalistic and modernist iteration of the moment, for being "decadent" and "cosmopolitan".

During the unfolding of the communist project in the USSR, Romania and other countries, the political discourse had elements of both continuity and discontinuity, sometimes resulting in ideological contradiction, confusion or paradox. This usually happened when some of the new elements of the ideology - that are adopted to respond to new circumstances - end up in a state of contradiction with some of the older concepts and ideas that are in use. An example would be the original internationalist character of communism (the Lenin era, with the Communist International) that transformed itself, during the Stalin era, into a more nationalist-oriented ideology (Boia, 1995). These changes in ideology always had an echo, more or less powerful or noticeable, inside the cultural agenda (including architecture and aesthetics).

In this context, the overarching idea is that the stylistic preferences of the communist project (whether it be socialist realism or other aesthetic orientations) aimed at being closely linked to the political and ideological messages that the communist project wanted to transmit at some point in its history, to a certain place on the map (whether it be Moscow, Bucharest, or Warsaw). Socialist realism developed in Russia/USSR in the 1920s and 1930s, and was then simply exported to the territories that came under the later sphere of influence of the USSR (including Romania). It entered the new territories as a form of Russian/Soviet cultural colonisation and acculturation. In the USSR at least, where the style had emerged, the socialist content of the buildings designed in a socialist-realist style can be considered satisfied by the use of communist symbols (the sickle and the hammer, the 5-point star), and by the programmes themselves (blocks of flats, clubs and cinemas for the working class). On the other hand, the goal of the "national form" can be considered satisfied by the use of the historicist stylistic quotations, while the styles that were considered worthy of being used were critically sorted and selected from the styles that would not be worthy of representing the national form.

Additionally, as socialist realism stood for socialist content in national form, this situation triggered confusion among designers, as the imported Soviet style was often seen as being "national" only to the USSR (to the Russian people), and not to the people of the satellite states of the Soviet Union, such as Romania. This contradiction is one of the reasons for which, when adopted in satellite states, the Russian-styled aesthetics of socialist realism had to adapt in order to become national to, for example, Romanians - and this dilemma would end up triggering other stylistic answers outside the typical features of socialist realism, mostly after the style would fade away. An example of this can be seen in the middle of the 1950s when socialist realism was at the peak of its influence in the architecture and urbanism practised in Romania, and an interesting observation can be made: although the projects were frequently imported from the USSR (Soviet project, Soviet architects), and more or less adapted by local Romanian architects for a Romanian site, some of the buildings employed decorative elements typical for Romania and not the USSR, such as decorative elements inspired by traditional, vernacular and folk architecture (Tulbure, 2016:p.105). The result is sometimes a mix of classical, Soviet communist and traditional Romanian motifs and symbols: "socialist content in national form" or eclecticism re-morphed.

\section{Post-Stalinism and destalinisation: the revision of socialist content in national form}

After Stalin's death in 1953, the new Soviet leader and head of the Communist Party of the Soviet Union, Khrushchev, adopted a political approach that has been labelled as destalinisation. Criticising some of the policies of the Stalin era, Khrushchev's ideas also included the field of construction works and architecture and, implicitly or indirectly, the topic of architectural styling. One of the most important points in his critique of the building practices of the Stalin era regarded the aspect of cost, deeming the buildings as often being unnecessarily expensive, too wasteful of resources, using unnecessary decoration and exaggerated sizes. Demanding cost reductions in building activities, and an increase in standardisation, 
Khrushchev marked the beginning of a new aesthetic era in USSR, with the (almost total) abolition of (added) ornament in the design of buildings, and a general shift towards functionalism. The socialist realism, with most of its characteristics, was now interrogated, criticised, partly condemned and partly abandoned.

Khrushchev's new ideas regarding the building sector were expressed in a series of discourses. Many scholars point to a discourse in 1954, and another in 1956, as being two of the most influential (Ioan, 2012:p.184). As the style began to change in the USSR, Romania witnessed an initial tempered resistance to the new ideas. Gheorghiu-Dej, the communist leader at the time in Romania, is frequently indicated to have delayed the adoption of the new policies coming from Moscow, as a means of aiming for a higher degree of autonomy from the USSR (Zahariade, 2011:p.54). Therefore, Romanian architecture continued within the framework of socialist realism for a few more years, eventually abandoning it by the end of the 1950s. GheorghiuDej's speech condemning socialist realism happens in 1958, making it a late correspondent to Khrushchev's speeches of 1954 and 1956 (Zahariade, 2011:p.55). The gradual abandonment of socialist realism is marked by a few years in which projects that had been designed using the socialist-realist method were finished or adapted, mostly conserving the layouts, sizes and the volumetric features, but lowering or eliminating applied decoration. This is a distinctive feature of the end of socialist realism in Romania, as other countries in the communist block witnessed more rapid transitions. In Hungary, for instance, socialist realism was abruptly abandoned following Khrushchev's critical assault on the method (Ioan, 2012:p.200).

With this short but not irrelevant delay, the aesthetic norms of Romanian architecture begin to shift towards a somewhat special type of functionalism and modernism, starting in 1958. However, the keywords functionalism or modernism are not adopted, which is understandable in the context of the "cold war" with Western capitalist culture, where the two terms were already established. Instead, "Soviet scientists" (a frequent idiom of the period) developed other notions, avoiding the use and the acknowledgement (both direct and indirect) of the keywords that were popular in the capitalist world. The basis of the new way of practising urbanism in the Soviet block was labelled "the scientific theory of the microraion" - which is, in its essence, a concept that has been included (by many architecture theorists) inside the wider conceptual framework of functionalism, free urbanism and modernism. Practically, Soviet urbanism replaces the cvartal (the basic working concept of configuration within the framework of socialist realism) with the microraion. In more recent years, the idiom "socialist modernism" has been used quite extensively in labelling this particular form of postwar modernism.

Turning to the more cost-effective buildings, mass social housing and widespread austere designs, it can be argued that, at least apparently, the new style maintained the "socialist content", but lost the "national form" (as it lost the historicist quotations to national values). Commenting on the stylistic shift that puts the overarching slogan of socialist content in national form in an apparent state of crisis, Zahariade argues that the slogan itself is not openly abandoned or criticised but only adapted to the new conditions and interests with national being replaced by adequate, economical, functional, rational or industrialised (Zahariade, 2011:p.55,142). The slogan is probably too important within communist ideology to be simply abandoned or dismantled. It is not openly dismissed, but rather silently revised, without actually mentioning the needed adaptation of the idea. Consequently, socialist content in national form becomes socialist content in rational/economical/functional form - but without saying it explicitly, as this would be dangerous from a propaganda perspective (see Fig. 2).

Moreover, the opinion of architect researcher Irina Tulbure comes relatively close to these observations, arguing that, for reasons of strategy regarding propaganda, the communist leaders usually avoided attacking the key ideas, concepts and methods of the ideology, but rather the results and the interpretations (Tulbure, 2016:p.94). According to Tulbure, "socialist realism" is not fully deemed wrong from a conceptual and ideological point of view, as this would be a threatening act to the stability and cohesion of the ideology. The needed upgrades to the major ideas, when they were necessary, could be better

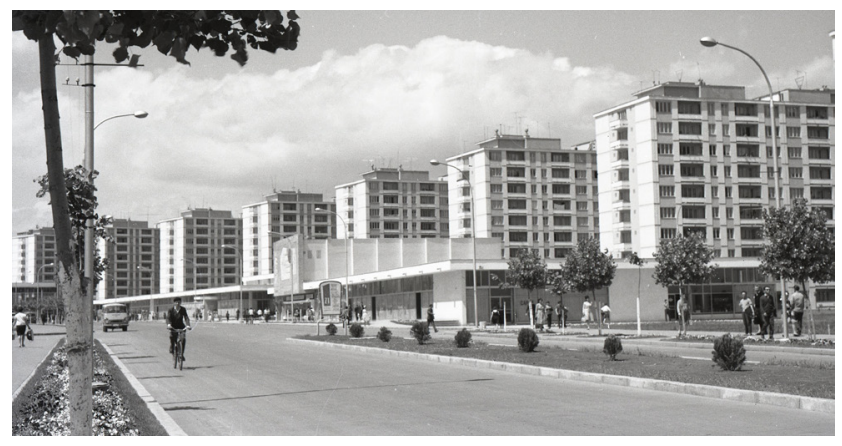

Fig. 2 Socialist content in rational/economical/functional form, 1960s, post-Stalin: blocks of flats and commercial complex in the town of Onești. (Oiță, 1965) 
managed with minimum damage to the politicians, who were not wrong in their ideas, but rather misunderstood by the individuals (including the professionals), whose jobs are to translate the ideas (content) into form, in this case, the architects (Tulbure, 2016:p.94). Augustin Ioan, another highly acclaimed architect in the field of history and theory of architecture in Romania, has a similar point of view. He states that the ideology that generated socialist realism is not explicitly attacked, nor are the key personalities that had a role in configuring the model (such as Stalin himself). What Khrushchev was aiming at was a review of the official view on architecture (Ioan, 2012:p.184). As for the socialist-realist method, Ioan argues that Khrushchev had to take a subtle approach on the matter, not just changing the aesthetic language via decree. It was a diagonal attack, via a tactic of encapsulation (Ioan, 2012:p.192).

\section{The Nicolae Ceaușescu era: Stalinism revised}

From around 1960 in Romania, the "national" half of the "socialist (content) - national (form)" dualism was arguably suspended. But it soon began to re-emerge from its apparently latent state some five years later, beginning in 1965, with the affirmation of Nicolae Ceaușescu as the new communist leader in Romania, following GheorghiuDej's death. Fuelled by a nationalistic fervour that was initiated to consolidate Romania's autonomy and independence from the USSR, Ceaușescu re-enacted the search for the national form in architecture, beginning with the first years of his mandate as supreme leader. The nationalistic agenda was also an element of Gheorghiu-Dej's policy, but it was Ceauşescu who developed a stronger nationalistic political drive. This drive would also have a visible echo in the field of architectural aesthetics, marking the reaffirmation of the idea of socialist content in national form (although rarely using the same words). On the other hand, maybe paradoxically, Romania's new constitution, which was adopted in 1965 at the beginning of Ceaușescu's mandate, no longer mentioned socialist content in national form as did the 1952 constitution.

However, this did not mean that the search for national forms in socialist content - now within a firm and affirmed nationalistic frame, under Ceauşescu - was abandoned. To be more specific, Ceaușescu is credited with having issued an important array of indications that demanded the emergence of a national style in architecture (Răuță, 2013:p.198; Zahariade, 2011:p.82-84,87). For example, in a speech from 1971, Ceauşescu criticises some of the aspects regarding architecture, urbanism and the building sector, declaring that "the architects have quite often neglected the rich traditional values of Romanian architecture, our national specificity" (Zahariade, 2011:p.60); the emphasis being "traditional values of Romanian architecture" and "national specificity". It can be argued that this is another way of demanding a search for an adequate national form in architecture, as in the national form that was demanded within the framework of the "socialist content in national form" slogan. Ceaușescu's speech from 1971 has frequently been interpreted as a general critique of that particular unassumed mix of functionalism and modernism - an approach that was dominating the professional discourse and practice at that time, having "produced" most of the built forms of the 1960s (extensive ensembles of collective housing, administrative buildings, houses of culture).

In a way, Ceaușescu's speech of 1971 criticises socialist modernism in a similar way to Gheorghiu-Dej's speech of 1958 that had criticised socialist realism, following Khrushchev's speeches. The result is that the approach, heavily rooted in functionalism and modernism, and based on "the scientific theory of the microraion", was questioned, partially condemned, and largely abandoned. In a correspondingly similar way with what had happened with socialist realism, the concept was not completely abandoned. Rather, the method was heavily revised, as to correspond to new realities and priorities. For example, Ceauşescu calls for a sort of recovery of the characteristic (and arguably traditional) image of the street: "the apartment buildings are dispersed randomly; they do not create streets and boulevards, in a clear urban idea" (Zahariade, 2011:p.60). Considering the issues that it addressed, Ceauşescu's speech of 1971 has sometimes been interpreted as a sort of political manifesto towards postmodernism, whether it was a conscious act, or something accidental (in its intentions). Whether true, false or partially true, following this speech, architecture and urbanism in Romania shifts away from mainstream modernism and functionalism, and begins to incorporate features of postmodernism.

It is important to note that some manifestations outside the framework of mainstream modernism and functionalism were already happening by 1971 , but they were more insular. As the 1960s had been years of relative openness to foreign (even Western) channels of communication, Romanian architects were relatively exposed to information about new trends and concepts in architecture. What they usually did was to filter the external ideas and to adopt them, usually fragmented, in their Romanian work. Postmodernist ideas are just one example, but 
echoes of brutalism, structuralism, metabolism or critical regionalism can also be traced (see Fig. 3 and Fig. 4). However, the 1970s and to a greater extent, the 1980s marked a return to a relative condition of cultural isolation, imposed by the Ceaușescu regime. Despite this, Romanian architects were not completely shut off from the new ideas concerning architecture and urbanism in the Western world (Zahariade et al., 2003:p.156).

The period between 1965 and 1970 is particularly interesting, as it marked the affirmation of an interesting aesthetic approach. Heavily influenced by the work of the architect Nicolae Porumbescu, the approach followed the desideratum of recovering and employing features and values of traditional Romanian architecture. Porumbescu is largely remembered and recognised to have transposed elements of traditional architecture into the modern buildings that he was designing. An evocative example is the transposition of traditional shapes (typical to specific

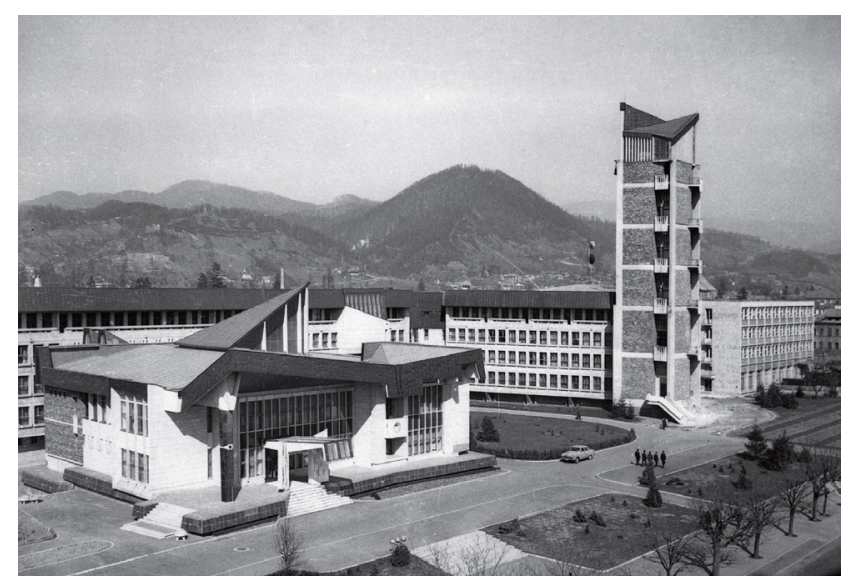

Fig. 3 Echoes of critical regionalism: county hall and county headquarters of the communist party in the city of Baia Mare, built 1969-1970 and designed by arch. Mircea Alifanti

(Zahariade and Ponta, 2014).

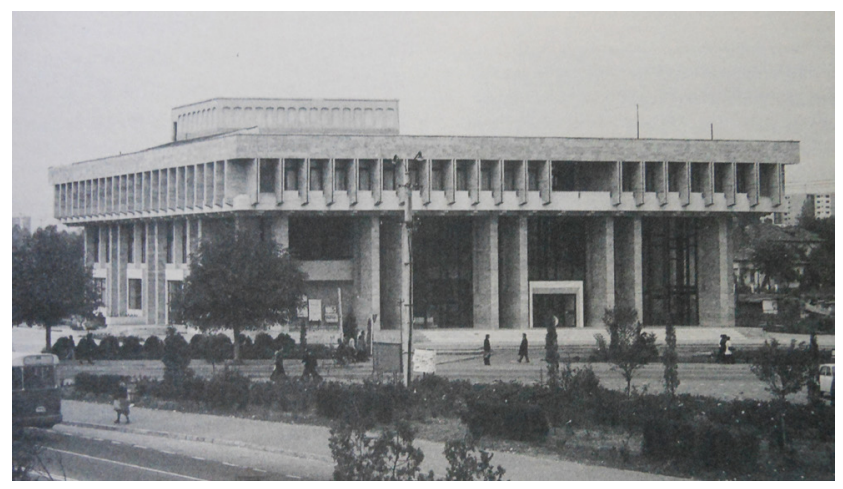

Fig. 4 Echoes of brutalism: the House of Culture of the town of Târgoviște, built 1969-1974 and designed by arch. Nicolae Vlădescu (Tulbure, 2017:p.54). ethnographic regions of Romania) into concrete, such as the suggestion of wooden joints in concrete forms (see Fig. 5). After or alongside Porumbescu, there are other architects, such as Constantin Joja, who are sometimes associated with this particular aesthetic approach, which could be labelled as "the traditionalistic group/movement" - although other labels can be encountered when addressing it including lyrical functionalism, traditional modernism, and national-communism.

The projects that can be included in this group were usually based on documentation and research campaigns aimed at understanding traditional Romanian architecture, the ultimate goal being to adequately transpose, into modern projects, some key traditional values and elements from the portfolio of traditional Romanian architecture. An example would be the architect Adrian Gheorghiu, whose professional preoccupations at the end of the 1960s are eloquently expressed through the titles of two articles that he published within Arhitectura magazine, the most important professional journal of the period: "Processing Romanian Folk Architecture" (Gheorghiu, 1967a) and "Romanian Specificity in Contemporary Architecture" (Gheorghiu, 1967b). Otherwise, Porumbescu himself is credited for writing an arguably influential article on the topic in 1967, within the pages of the same Arhitectura magazine. The name of the article is "Specificity in Architecture", and Porumbescu uses it to explain elements of his architectural designs and concepts, also elaborating on the idea of the lyrical potential of reinforced concrete (Porumbescu and Vaida-Porumbescu, 1967).

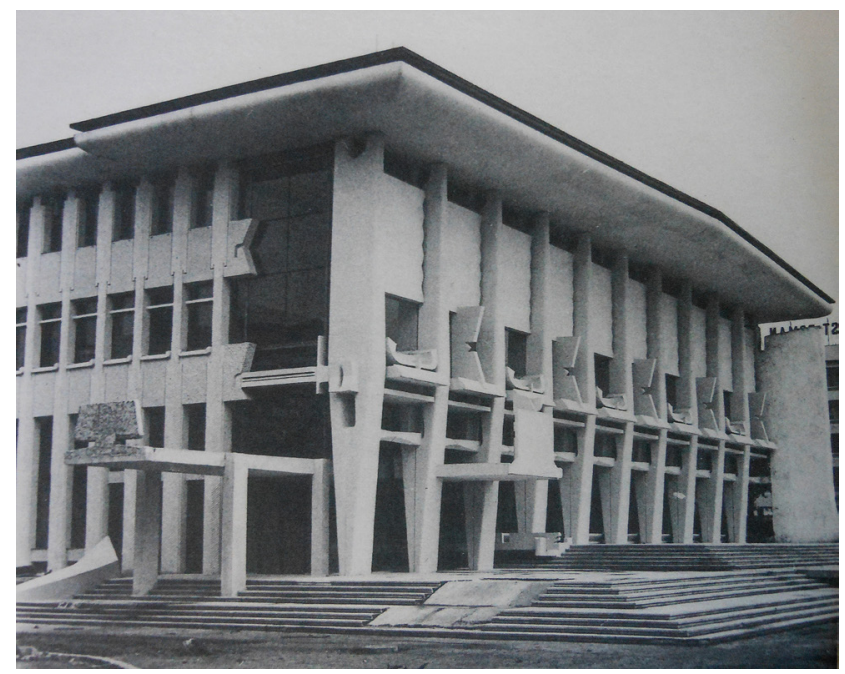

Fig. 5 "Socialist content in national form" resuscitated, the end of the 1960s, Ceauşescu-era: the "traditionalistic" approach: the House of Culture from the town of Suceava, inaugurated in 1969 and designed by arch. Nicolae Porumbescu (Tulbure, 2017:p.66). 
This particular approach, via the vernacular and traditional, seemed to correspond to Ceaușescu's demands for a Romanian specificity and national character in architecture, as most of the buildings designed in this manner were broadly appreciated by the dictator (Tulbure, 2017, p. 68). By the beginning of the 1970s, it can be clearly seen that the search for national form had reached the forefront of Romanian architecture, alongside the usual central themes of cost reduction, standardisation, and systematisation (see Fig. 6). The resort to national Romanian specificity in architectural forms usually followed the traditionalistic approach, and blocks of flats began to employ prefabricated façade panels decorated with traditional motifs executed mostly in concrete or plaster, including geometric patterns typical of traditional rugs, chopped wood patterns and arches. Other less frequent approaches were also present, such as more postmodern-oriented quotes of archetypes, through an attitude of irony or ludic interplay between old and new.

By the end of the communist era, in the second part of the 1980s, the capital city (Bucharest) witnessed the emergence of what is frequently remembered as the ultimate embodiment of the Ceaușescu-era approach on architectural aesthetics: the Civic Centre, with the massive

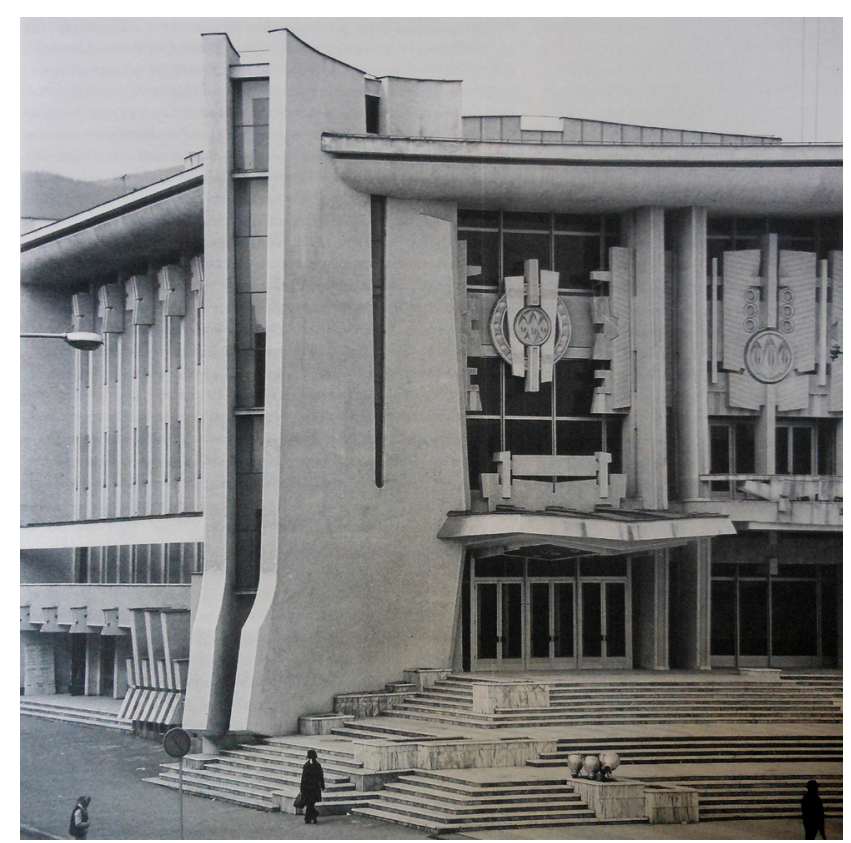

Fig. 6 "Socialist content in national form" morphed into the Ceaușescuera "national style"; 1970s: the development of the "traditionalistic" approach: the House of Culture from the town of Deva, inaugurated in 1975 and designed by arch. Cornel Florea (Tulbure, 2017:p.70).
House of the People and the urban ensemble surrounding the boulevard of the Victory of Socialism and a few urban squares. Here, the use of decoration, monumentality and sheer size was massive, reaching extreme proportions. The decorative approach of both exterior and interior space is particularly evocative, as it employs references, quotes and replicas from a wide array of styles including Italian Renaissance, Greek classicism, Roman classicism, French Beaux-Arts, neo-Romanian, and even Art Deco.

Although an impressive number of architects were involved in the project, many Romanian architects appreciate that the true architect of the Civic Centre was Ceauşescu himself, due to his huge involvement in the design (Celac, 1995:p.195). This is ultimately evocative of the dictator's tastes regarding architectural and urban aesthetics ideas that were not difficult to impose upon the professionals if he wanted to, considering the power that he had, as supreme leader. Therefore, the Ceaușescu-era approach happened in a way somewhat similar to the Stalinist episode - this being one of the reasons for which the architectural production of the Ceaușescu era (1965-1989) is sometimes described as neo-Stalinist or Stalinism revival alongside the more acknowledged term of "national-communist style", or simply "the Ceaușescu style".

Although the search for a national form in architecture was a clear feature of the Ceaușescu period, as the previous paragraphs have tried to demonstrate, the actual use of the slogan "socialist content in national form" was quite rare in Ceauşescu's mandate. Considering its fall from regular and frequent use since Khrushchev's and GheorghiuDej's critique of socialist realism (1954-1956-1958), it can be argued that the slogan had actually (or mostly) disappeared with Stalin's death in 1953, and the subsequent criticism of socialist realism via Khrushchev. From a formal and superficial point of view, the affirmation is true, although, from a broader perspective, it can be noticed that the slogan never actually left the scene of the political discourse concerning architecture, according to Ana Maria Zahariade (Zahariade, 2011:p.51). It can be argued that, even if the slogan ceased to make the headlines after the period of the socialist realism, it had already influenced the politicians in a profound way. The slogan was part of their education, as a key principle of communism and Ceauşescu is an eloquent example for this, as his behaviour is often interpreted to have been heavily influenced by Stalinist methods (Zahariade, 2011:p.61,103). 


\section{Conclusion}

As the unfolding of data, ideas and comments in this article have tried to reveal, "socialist content in national form" has been one of the most influential concepts of the communist project, laying its mark on Romanian architecture, both directly and indirectly, in the entire period that is commonly referred to as "the communist times". Its moment of irrefutable influence was the Stalinist period when it was used extensively in the political and ideological discourse and was even introduced into Romania's constitution of 1952. After Stalin's death (1953) and the criticism of Stalinism

\section{References}

Boia, L. (1995) "Cele două fețe ale mitologiei comuniste" (The Two Faces of Communist Mythology), In: Boia, L. (ed.) Miturile Comunismului Românesc, Bucharest University Press, Bucharest, Romania, pp. 7-16. (in Romanian)

Celac, M. (1995) "O analiză comparată a limbajului totalitar în arhitectură" (A Comparative Analysis of Totalitarian Language in Architecture), In: Boia, L. (ed.) Miturile Comunismului Românesc, Bucharest University Press, Bucharest, Romania, pp. 181-206. (in Romanian)

Dőri, E. (1959) "Heirs of András Sütő: Înfrățirea între popoare cinema, Bucurestii Noi district; Új Élet Magazine", [online] Available at: https://www.azopan.ro/?y=1959\#3943|1959|en [Accessed: 23 February 2020]

Gheorghiu, A. (1967a) "Prelucrări de arhitectură populară românească" (Processing Romanian Folk Architecture), Arhitectura, 2, pp. 42-46. (in Romanian)

Gheorghiu, A. (1967b) "Un specific românesc în arhitectura contemporană" (Romanian Specificity in Contemporary Architecture), Arhitectura, 3, p. 3. (in Romanian)

Ioan, A. (2012) "Arhitectura (supra) realismului socialist" (The Architecture of the socialist (supra) realism), Paideia, Bucharest, Romania. (in Romanian)

Oiță, F. (1965) "Centrul comercial al orașului - Cinematograf, magazinul general Victoria, blocuri de locuit" (The Commercial Centre of the City - Cinema, Victoria general store, blocks of flats), [online] Available at: https://arhiva.uniuneaarhitectilor.ro/a-219/ centrul-comercial-al-orasului-cinematograf-magazinul-general-victoria-blocuri [Accessed: 23 February 2020] (in Romanian) by the new Soviet leader Khrushchev $(1954,1956)$ and Romania's leader Gheorghiu-Dej (1958), the slogan entered a period in which its direct influence on Romanian architecture began to decline or to blur. This situation continued until 1965 when Ceaușescu came to power - displaying a bold nationalistic inclination that ended up resurrecting the slogan in a new conjugation, using mostly other words and associations of words, but conserving the essence of the concept. Therefore, "socialist content in national form" can be considered to have acted as a "red line" in the history of Romanian architecture in the communist project.

Porumbescu, N., Vaida-Porumbescu, M. (1967) "Specificul în arhitectură" (Specificity in Architecture), Arhitectura, Number 2, pp. 12-17. (in Romanian)

Răuță, A., (2013) "Negotiating the Civic Center. Architects and Politicians in 20th Century Romania", Ion Mincu University Press, Bucharest, Romania.

Shelestyuk, E. (2019) "National in Form, Socialist in Content: USSR National and Language Policies in the Early Period", SHS Web of Conferences, 69, Article number: 00104. https://doi.org/10.1051/shsconf/20196900104

Tulbure, I. (2016) "Arhitectura și urbanism în România anilor 19441960: constrângere şi experiment" (Architecture and Urbanism in Romania of the years 1944-1960: constraint and experiment), Simetria, Bucharest, Romania. (in Romanian)

Tulbure, I. (2017) "What is a House of Culture Today?", In: Şerban, A. (ed.) The Factory of Facts and Other (Unspoken) Stories, Pepluspatru, Bucharest, Romania, pp. 46-73.

Zahariade, A. M. (2011) "Architecture in the Communist Project. Romania 1944-1989", Simetria, Bucharest, Romania.

Zahariade, A. M., Ioan, A., Celac, M. (2003) "Teme ale arhitecturii din România secolului XX" (Themes of 20th-century Romanian architecture), Romanian Cultural Institute, Bucharest, Romania. (in Romanian)

Zahariade, A. M., Ponta, R. (2014) "Professor Alifanti's Notebooks", sITA, 2, pp. 163-187. [online] Available at: https://sita.uauim. ro/2/a/20/ [Accessed: 23 February 2020] 